\title{
PERTANGGUNGJAWABAN PIDANA PENCEMARAN LINGKUNGAN HIDUP YANG DILAKUKAN OLEH KORPORASI
}

\author{
Muhari Agus Santoso \\ Fakultas Hukum Universitas Merdeka Malang \\ Jl. Terusan Raya Dieng No. 62-64 Malang \\ Muhari_Agus@unmer.ac.id
}

\begin{abstract}
Research on criminal liability of environmental pollution by corporations, multinational corporations have shown a massive accumulation of wealth and created a wide range of personalities. Whereas in the field of criminal law, which is heavily linked to accountability referred to in the Criminal Code (KUHP) only recognizes individuals as the subject of criminal law. Corporations not yet seen as a subject of criminal law. However, in subsequent developments, it is mentioned in the special criminal law. The relationship with vicarious liability or corporate liability in criminal law can be described as the imposition of criminal responsibility to a person in the capacity of the principal offender, based on the offense or at least an element of offense committed by another person. The person who acts, however, must be responsible only for his actions. It takes firmness to put the corporate criminal responsibility on the environmental offense so that the corporation that carries out negligence in exploiting nature causing pollution can be punished according to its fault. Similarly, socialization is needed to society about the possibility of environmental depictions that must be accounted by the corporation. It is so important to capture community participation in maintaining environmental wisdom.
\end{abstract}

Keywords: Criminal Liability, Environmental Pollution, Corporation.

\begin{abstract}
ABSTRAK
Penelitian tentang pertanggungjawaban pidana pencemaran lingkungan hidup yang dilakukan oleh korporasi, korporasi multinasional telah menunjukkan akumulasi kekayaan besar-besaran, dan menciptakan jarak yang lebar antar personal. Bahwa pada lapangan hukum pidana, yang berat berkait dengan pertanggungjawaban disebut dalam Kitab Undang-undang Hukum Pidana (KUHP) hanya mengenal perseorangan sebagai subjek hukum pidana. Korporasi belum dipandang sebagai subjek hukum pidana. Akan tetapi, dalam perkembangan selanjutnya disebutkan dalam hukum pidana khusus. Hubungannnya dengan vicarious liability atau pertanggungjawaban korporasi didalam hukum pidana dapat digambarkan sebagai pengenaan pertanggungjawaban pidana kepada seseorang dalam kapasitas pelaku utama, berdasarkan atas perbuatan pelanggaran atau sekurang-kurangnya ada unsur pelanggaran yang dilakukan oleh orang lain. Orang yang berbuat, bagaimanapun juga harus bertanggungjawab sebatas perbuatannya tersebut. Diperlukan ketegasan untuk meletakkan tanggungjawab pidana korporasi pada delik lingkungan hidup sehingga korporasi yang melakukan keteledoran dalam mengeksploitasi alam yang menyebabkan pencemaran dapat dipidana sesuai degan kesalahannya. Demikian pula dibutuhkan sosialisasi kepada masyarakat tentang berbagai kemungkinan adanya delik lingkungan yang harus dipertanggungjawabkan oleh korporasi. Hal demikian penting untuk menjaring peranserta masyarakat dalam menjaga kearifan lingkungan hidup.
\end{abstract}

Kata kunci: Pertanggungjawaban Pidana, Pencemaran Lingkungan, Korporasi. 
Permasalahan yang berkenaan dengan Badan Hukum, khususnya berupa Korporasi terus berkembang. Tidak saja dalam lapangan hukum perdata, namun juga dalam lapangan hukum Administrasi dan lapangan hukum pidana. Justru dalam lapangan hukum pidana ini menjadi satu perkembangan menarik, terutama dalam hal pertanggungjawabannya. Menelusuri perkembangan Badan Hukum berupa korporasi mulai dari abad pertengahan hingga abad ini, cukup memberikan informasi untuk mencari hubungan antara pertumbuhan korporasi yang pesat dengan timbulnya kejahatan korporasi dalam lapangan hukum pidana dimaksud.

Dewasa ini, Korporasi multinasional telah menunjukkan akumulasi kekayaan besar-besaran, bahkan menurut Barnet dan Muller, aset fisik yang dimiliki oleh korporasi global pada tahun 1974 telah mencapai lebih dari \$200 miliar. Implikasi dari bisnis dunia yang didominasi oleh korporasi besar tersebut, telah memasuki semua aspek kehidupan manusia. Karena, dapat menentukan pekerjaan bagi banyak orang, makanan, minuman dan pakaian, dan sebagainya. Di samping itu, suatu korporasi dapat pula mengancam pemerintahan suatu negara di mana korporasi itu beroperasi.

Hal itu dilakukan, apabila kebijakan yang dibuat oleh pemerintah tidak menguntungkan korporasi yang bersangkutan, yaitu dengan cara memindahkan usahanya ke negara lain yang mempunyai ketentuan hukum yang lemah dalam pengaturan masalah pencemaran lingkungan hidup atau standar keamanan kerja yang lemah, atau upah buruh yang murah. Tindakan eksodus seperti itu biasanya lalu ditakuti, karena akan berakibat pada masalah pengangguran. Akibat selanjutnya, muncul berbagai komentar bahkan debat di televisi, yang sesekali menyudutkan pemerintah sebagai suatu koreksi atas kebijakan yang dijalankan. Mungkin juga termasuk mengenai Corporate Social Responsibility (CSR).
Mengahadapi korporasi yang demikian itu, pemerintah mengalami kesulitan dalam mengaturnya atau mengontrolnya. Umumnya korporasi mempunyai penasihat hukum yang mumpuni, sehingga mampu untuk menentukan apa yang harus dilakukan untuk menghindari kebijakan yang tengah dijalankan oleh Negara yang nantinya diperkirakan akan dapat mengurangi keuntungannya. Tidak hanya itu, korporasi juga dapat atau mampu memainkan hukum suatu negara dengan tujuan, untuk mengurangi kontrol yang dilakukan oleh negara. Ini menunjukkan, bahwa betapa besarnya kekuatan yang dimiliki oleh suatu kor porasi.

Di Indonesia, akhir-akhir ini, bukan saja jumlahnya yang semakin meningkat melainkan munculnya korporasi raksasa, karena disertai dengan meningkatnya diversifikasi di bidang usaha oleh perusahaan-perusahaan raksasa tersebut, melalui usaha bersama di antara perusahaan domestik maupun perusahaan-perusahaan luar negeri, telah mendorong meningkatnya korporasi multinasional dan transnasional.

Apalagi, dengan ditetapkannya program industrialisasi oleh pemerintah pada Pembangunan Lima Tahun Ketujuh semasa pemerintahan Orde Baru (Tap MPR Nomor II/MPR/1998 tentang Garis Besar Haluan Negara diperbaharui dengan GBHN lima tahunan berikutnya). Pada bagian Prioritas Pembangunan Lima Tahun Ketujuh, dikemukakan: "Penataan dan pemantapan industri nasional yang mengarah pada perluasan, penguatan, dan pendalaman struktur industri nasional yang makin kokoh dengan penyebarannya ke seluruh wilayah Indonesia sesuai dengan potensi daerah".

Atas dasar gambaran di atas, masalah yang diteliti adalah seputar delik lingkungan yang dilakukan oleh korporasi. Tragedi mutakhir abad ini di lapangan lingkungan hidup adalah tejadinya pencemaran lingkungan di Sidoarjo oleh PT. Lapindo Brantas mulai tanggal 29 Mei 2006 sampai 
sekarang, yang menjadi korban tidak hanya penduduk sekitar, tetapi juga dunia usaha. Bahkan, mereka yang akan bepergian melalui bandara Juanda-Surabaya, dan harus lewat lokasi semburan, menjadi khawatir karena macet, khawatir ditinggalkan pesawat.

Namun demikian, keberpihakan pemerintah bukannya kepada masyarakat yang menjadi korban, akan tetapi justru kepada PT. Lapindo Brantas. Yaitu dengan terbitnya Peraturan Presiden No. 14 Tahun 2007 Tentang Badan Penanggulangan Lumpur Sidoardjo. Hal itu merupakan upaya terjadinya politisasi hukum pidana. Sebab ada petinggi yang terlibat, kemudian hendak bersembunyi di balik Peraturan Presiden tersebut.

Sehubungan dengan adanya ketentuan dalam Pasal 74 Undang-undang No. 40 Tahun 2007 tentang Perseroan Terbatas (Lembaran Negara Tahun 2007 Nomor 106, tanggal 16 Agstus 2007) yang mengatur mengenai Corporate Social Responsibility (CSR) ternyata telah menimbulkan dua pandangan yang saling berlawanan antara yang memuji atas kebijakan tersebut dan yang mengkritik karena dipandang memberatkan dunia usaha.

Terlepas dari dua pandangan yang berseberangan itu masalahnya adalah apa yang hendak dibidik oleh pembuat undang-undang sehingga CSR dimasukan ke dalam ketentuan Pasal 74 Undang-undang Nomor 40 Tahun 2007. Penjelasan Umum Undang-Undang Nomor 40 Tahun 2007 dikemukakan: "Dalam Undang-undang ini diatur mengenai Tanggugjawab Sosial dan Lingkungan yang bertujuan mewujudkan pembangunan ekonomi berkelanjutan guna meningkatkan kualitas kehidupan dan lingkungan yang bermanfaat bagi Perseroan itu sendiri, komunitas setempat, dan masyarakat pada umumnya.

Ketentuan di atas dimaksudkan untuk mendukung terjalinnya hubungan Perseroan yang serasi, seimbang, dan sesuai dengan lingkungan, nilai, norma, dan budaya masyarakat setempat.
Maka ditentukan bahwa Perseroan yang kegiatan usahanya di bidang dan/atau berkaitan dengan sumber daya alam wajib melaksanakan Tanggungjawab Sosial dan Lingkungan. Untuk melaksanakan kewajiban Perseroan tersebut, kegiatan Tanggungjawab Sosial dan Lingkungan harus dianggarkan dan diperhitungkan sebagai Perseroan yang dilaksanakan dengan memperhatikan kepatutan dan kewajaran.

Kegiatan tersebut dimuat dalam laporan tahunan Perseroan. Dalam hal Perseroan tidak melaksanakan Tanggungjawab Sosial dan Lingkungan, maka Perseroan yang bersangkutan dikenai sanksi sesuai dengan ketentuan peraturan perundang-undangan".

Mencermati Penjelasan Umum tersebut, tampak bahwa pembentuk undang-undang hendak menciptakan hubungan Perseroan yang serasi, seimbang, dan sesuai dengan lingkungan, nilai, norma, dan budaya masyarakat setempat. Kehendak untuk menciptakan hubungan yang sedemikian itu, sebenarnya adalah demi kelangsungan Perseroan itu sendiri, dan masyarakat sekitar merupakan bagian dari Perseroan, dan sebaliknya. Filosofisnya adalah harmonisasi.

Namun demikian, seperti yang telah saya singgung di atas, ketentuan dalam Pasal 74 UndangUndang Nomor 40 Tahun 2007, telah banyak menuai kritikan. Di antaranya dari Ketua Umum Kadin Mohamad S. Hidayat, yang mengatakan bahwa CSR adalah kegiatan di luar kewajiban perusahaan yang umum dan sudah ditetapkan dalam perundang-undangan formal, seperti ketetiban usaha, pajak atas keuntungan dan standar lingkungan hidup. Jika hal itu diatur, selain bertentangan dengan prinsip kerelaan, CSR juga memberi beban baru kepada dunia usaha. Ketua Umum Kadin itu, dalam upaya memperkuat argumentasinya membandingkan dengan Negara Eropa, walaupun secara institusional jauh lebih matang dari Indonesia. Ia menyatakan bahwa CSR bukan sesuatu yang harus diatur. 
Pendapat Ketua Kadin tersebut patut dipertanyakan, apakah kepentingan hukum Negaranegara Eropa yang disebutkan itu sama dengan Indonesia. Perkembangan legislatif di Indonesia memang cenderung bahwa harus ditulis/diatur. Meskipun diakui nilai budaya setempat, karena di negeri ini, jangankan tidak diatur dalam arti tidak ditulis dalam peraturan perundang-undangan, yang diatur saja suka dilanggar. Tentunya juga untuk menjamin ketaatan ketentuan yang diatur itu, diperlukan adanya sanksi.

Relevan diklarifikasi perkembangan subjek hukum dalam hukum pidana, baik dalam Kitab Undang-undang Hukum Pidana (KUHP) maupun di luar KUHP. Juga dalam RUU KUHP 2007, serta komentar para pakar hukum pidana. Selanjutnya, mengenai pertanggungjawaban pidana korporasi kaitannya dengan ketentuan Pasal 74 Undangundang Nomor 40 Tahun 2007, didasarkan pada tiga pilar dalam hukum pidana. Yaitu tindak pidana, kesalahan, dan pemidanaan. Kemudian, mengenai tanggung jawab korporasi terhadap korban dengan pendekatan konsep daad-dader-slachtoffer-strafrecht.

Menurut Jonkers, meskipun korporasi tidak dapat begitu saja dipertanggungjawabkan dalam hukum pidana, tetapi dalam kenyataannya korporasi sering melakukan tindak pidana. Namun, di Belanda telah terjadi perkembangan, pada tahun 1976 pembentuk Undang-undang memutuskan untuk merubah Pasal 51 Kitab Undang-undang Hukum Pidana berdasarkan Undang-undang tanggal 23 Juni 1976, Lembaran Negara Nomor 377.

Menurut ketentuan yang baru ini, semua tindak pidana dapat dilakukan oleh orang dan korporasi. Ketentuan yang tercantum dalam Pasal 51 itu telah ada sejak tahun 1951 dalam hukum pidana ekonomi (Pasal 15 Economic Penal Code). Akan tetapi, ketentuan pasal dalam bidang ekonomi tersebut telah dicabut pada tahun 1976, dan itu telah disebutkan dalam Pasal 51 yang baru, yang berarti telah mengakhiri doktrin fiksi.
Perundangan yang baru itu, berlaku untuk hukum pidana umum dan hukum pidana ekonomi, yaitu berdasarkan ide bahwa korporasi merupakan badan hukum dan dapat melakukan tindak pidana. Selanjutnya, suatu hal yang perlu dikemukakan adalah yang berkaitan dengan jenis pelaku yang terdiri dari orang dan korporasi itu. Pengertian korporasi yang digunakan oleh Kitab UndangUndang Hukum Pidana Belanda berbeda dengan pengertian korporasi dalam hukum perdata, juga badan hukum yang bukan berbentuk badan hukum dipandang sebagai korporasi dan dapat dikenai pertanggungjawaban pidana berdasarkan Pasal 51.

Tentang bagaimana pertanggungjawaban pidana korporasi kaitannya dengan ketentuan pasal 74 Undang-undang Nomor 40 tahun 2007, menurut Packe bahwa dasar rasional dari hukum pidana bersandar pada tiga konsep, yaitu tindak pidana, kesalahan, dan pemidanaan. Lebih lanjut Packer bahwa ketiga konsep tersebut melambangkan tiga permasalahan pokok dalam hukum pidana, yaitu; a) perbuatan apa yang seharusnya dianggap sebagai kejahatan, b) ketentuan-ketentuan atau syaratsyarat apa yang harus dibuat sebelum seseorang dapat dinyatakan telah melakukan tindak pidana, c) apa yang seharusnya dilakukan terhadap seseorang yang telah diketahui melakukan tindak pidana.

Ketiga pilar tersebut, merupakan titik tolak untuk mengkaji pertanggungjawaban pidana korporasi dalam hubungannya dengan pengabaian kewajiban sebagaimana yang ditentukan dalam Pasal 74 Undang-undang Nomor 40 Tahun 2007 tentang Perseroan Terbatas. Dengan demikian, ruang lingkup pembahasan ini meliputi; perbuatan pidana, pertanggungjawaban pidana korporasi, dan pidana dan pemidanaan.

\section{Pertanggungjawaban Pidana dalam Perspektif Undang-Undang Perlindungan dan Pengelolaan Lingkungan Hidup.}

Bahwasanya pendekatan hukum pidana tidak sebagai upaya terakhir yang lazim disebut 
dengan istilah "ultimum remedium" untuk menghukum perilaku usaha yang menimbulkan masalah lingkungan hidup. Dalam UULH 1997 sanksi pidana menjadi upaya terakhir setelah penegakan hukum administrasi negara tidak efektif. UU PPLH, "ultimum remedium" hanya berlaku untuk satu Pasal saja, yaitu Pasal 100 UUPPLH yang menyatakan (1) Setiap orang yang melanggar baku mutu air limbah, baku mutu emisi, atau baku mutu gangguan dipidana dengan pidana penjara paling lama 3 (tiga) tahun dan denda paling banyak Rp.1.000. 000.000, 00. (2) Tindak pidana sebagaimana dimaksud pada ayat (1) hanya dapat dikenakan apabila sanksi administratif yang telah dijatuhkan tidak dipatuhi atau pelanggaran dilakukan lebih dari satu kali.

Rumusan Pasal 100 Ayat (2) jelas dapat dipahami bahwa sanksi pidana yang tercantum dalam Pasal 100 Ayat (1) baru dapat dikenakan jika sanksi administratif tidak efektif atau pelanggaran dilakukan berulang. Hal ini berarti sanksi pidana berfungsi sebagai upaya terakhir. Perspektif ini, UU PPLH telah secara tegas meletakkan pertanggungjawaban pidana kepada pimpinan badan usaha yang telah menimbulkan pencemaran atau perusakan lingkungan hidup. UU LH 1997 tidak disebut secara tegas pimpinan atau pengurus badan usaha dapat dikenai pertanggungjawab pidana. UU LH 1997 hanya menggunakan istilah "yang memberi perintah" atau "yang bertindak sebagai pemimpin" dalam tindak pidana. UU PPLH 2009 pertanggungjawaban pidana pimpinan badan usaha dirumuskan dalam Pasal 116 hingga Pasal 119.

Namun demikian, UU PPLH tetap mengadopsi pertanggungjawab badan usaha (corporate liability). Pasal 116 UU PPLH memuat kriteria bagi lahirnya pertanggungjawaban badan usaha dan siapa-siapa yang harus bertanggungjawab. Jika dianalisa rumusan Pasal 116 UUPPLH, pertanggungjawaban badan usaha timbul dalam salah satu kondisi berikut yaitu (1) tindak pidana lingkungan hidup dilakukan oleh badan usaha, atau atas nama badan usaha atau (2) oleh orang yang berdasarkan hubungan kerja atau berdasarkan hubungan lain yang bertindak dalam lingkup kerja badan usaha. Karena badan usaha tidak dapat bekerja tanpa digerakkan oleh manusia, maka pelaku fisik tetaplah manusia, yaitu orang atas nama badan usaha atau orang yang berdasarkan perjanjian kerja, misalkan seorang karyawan atau hubungan lain, misalkan perjanjian pemborongan kerja.

Hal penting berikutnya adalah menentukan siapakah yang harus bertanggungjawab jika sebuah tindak pidana lingkungan hidup dinyatakan telah dilakukan oleh badan usaha atau korporasi. Pasal 116 Ayat (1) menyebutkan "tuntutan pidana dan sanksi pidana dijatuhkan kepada; (a) badan usaha dan/ atau (b) orang yang memberi perintah untuk melakukan tindak pidana tersebut atau orang yang bertindak sebagai pemimpin dalam tindak pidana tersebut." Selain itu, konsep pertanggungjawaban juga harus dipedomani ketentuan Pasal 118 UU PPLH yang menyatakan bahwa "Terhadap tindak pidana sebagaimana dimaksud dalam Pasal 116 Ayat (1) huruf a, sanksi pidana dijatuhkan kepada badan usaha yang diwakili oleh pengurus yang berwenang mewakili di dalam dan di luar pengadilan sesuai dengan peraturan perundang-undangan selaku pelaku fungsional".

Dengan demikian, dari rumusan Pasal 116 dan Pasal 118 UUPPLH dapat diketahui bahwa ada tiga pihak yang dapat dikenai tuntutan dan hukuman ada tiga pihak yaitu; a) badan usaha itu sendiri, b) orang yang memberi perintah atau yang bertindak sebagai pemimpin dalam tindak pidana, c) pengurus.

Tanpa rumusan Pasal 118 UUPPLH yang menyebutkan "sanksi dikenakan terhadap badan usaha yang diwakili oleh pengurus yang berwenang mewakili di dalam dan di luar pengadilan sesuai dengan peraturan perundang-undangan selaku pelaku fungsional", pengurus tetap juga dapat dikenai pertanggungjawaban atas dasar kriteria 
"orang yang memberi perintah atau orang yang bertindak sebagai pemimpin dalam tindak pidana" sebagaimana dirumuskan dalam Pasal 116 Ayat (1) Huruf $b$.

Perbedaannya adalah rumusan Pasal 116 Ayat (1) Huruf b memang mengharuskan penyidik dan penutut umum untuk membuktikan bahwa penguruslah yang telah bertindak sebagai orang yang memberi perintah atau yang bertindak sebagai pemimpin dalam tindak pidana, sehingga memerlukan kerja keras penyidik dan penuntut umum untuk membuktikan peran para pengurus dalam tindak pidana lingkungan.

Sebaliknya, menurut ketentuan Pasal 116 Ayat (1) Huruf b dikaitkan dengan Pasal 118, pengurus karena jabatannya secara serta merta atau otomatis memikul pertanggungjawaban pidana, sehingga lebih memudahkan dalam upaya penuntutan karena tidak membutuhkan pembuktian peran para pengurus secara spesifik dalam sebuah peristiwa pidana lingkungan.

Penjelasan Pasal 118 UU PPLH memperkuat interpretasi bahwa jika badan usaha melakukan pelanggaran pidana lingkungan, tuntutan dan hukuman "dikenakan terhadap pimpinan badan usaha atas dasar pimpinan perusahaan yang memiliki kewenangan terhadap pelaku fisik dan menerima tindakan tersebut". Pengertian "menerima tindakan tersebut" adalah "menyetujui, membiarkan atau tidak cukup melakukan pengawasan terhadap tindakan pelaku fisik, atau memiliki kebijakan yang memungkinkan terjadinya tindak pidana tersebut."

Rumusan ketentuan dan penjelasan Pasal 118 UU PPLH merupakan sebuah terobosan atau kemajuan jika ditilik dari segi upaya mendorong para pengurus perusahaan agar secara sungguhsungguh melaksanakan upaya pencegahan, pengendalian dan pemulihan pencemaran atau perusakan lingkungan manakala memimpin sebuah badan usaha. Rumusan Ketentuan Pasal 118 UU PPLH mirip dengan vicarious liability dalam system hukum
Anglo Saxon.

Perspektif ini, UU PPLH juga memuat delik materil yang diberlakukan kepada pejabat pemerintah yang berwenang dibidang pengawasan lingkungan. pemberlakukan delik materil ini dapat dipandang sebagai sebuah kebijakan pemidanaan yang maju dalam rangka mendorong para pejabat pemerintah untuk sungguh-sungguh melaksanakan pengelolaan lingkungan hidup. Delik materil tersebut dirumuskan dalam Pasal 112 UUPPLH yaitu, "Setiap pejabat yang berwenang yang dengan sengaja tidak melakukan pengawasan terhadap ketaatan penanggungjawab usaha dan/atau kegiatan terhadap peraturan perundang-undangan dan izin lingkungan, sebagaimana dimaksud dalam Pasal 71 dan Pasal 72 yang mengakibatkan terjadinya pencemaran dan atau kerusakan lingkungan yang mengakibatkan hilangnya nyawa manusia, dipidana dengan pindan penjara paling lama 1 (satu) tahun atau denda paling banyak Rp. 500.000.000, 00 (lima ratus juta rupiah).

\section{Tanggungjawab Korporasi dalam Delik Lingkungan Hidup}

Proses modernisasi dan pembangunan ekonomi, kenyataan menunjukan bahwa korporasi memegang peranan penting dalam kehidupan masyarakat. adapun dalam perkembangannya tidak jarang korporasi dalam mencapai tujuannya melakukan aktivitas-aktivitas yang menyimpang atau kejahatan dengan modus operandi yang dilakukan badan usaha. Oleh karena itu, kedudukan korporasi sebagai subyek hukum (keperdataan) telah bergeser menjadi subyek hukum pidana.

Di satu sisi, ditinjau dari bentuk subyek dan motifnya, kejahatan korporasi dapat dikategorikan dalam white collar crime dan merupakan kejahatan yang bersifat organisatoris. Untuk itu penekanannya pada struktur korporasi, hak dan kewajiban serta pertanggungjawabannya, sehingga dapat dikenali karakter kejahatan korporasi dan letak per- 
tanggungjawabannnya yang pada akhirnya dapat ditemukan solusi yuridisnya.

Adapun korporasi menurut Utrech dirumuskan bahwa korporasi adalah suatu gabungan orang yang dalam pergaulan hukum bertindak bersama-sama sebagai subyek hukum tersendiri suatu personifikasi. Korporasi adalah badan hukum yang beranggota, tetapi mempunyai hak dan kewajiban sendiri terpisah dari hak dan kewajiban anggota masing-masing.

Pemahaman tentang korporasi atau badan hukum adalah suatu perseroan yang merupakan badan hukum, korporasi atau peseroaan di sini yang dimaksud adalah suatu kumpulan atau organisasi yang oleh hukum diperlakukan seperti manusia (personal) ialah sebagai pengembang (atau pemilik) hak dan kewajiban memiliki hak menggunggat atau digugat dimuka pengadilan. Contoh badan hukum ialah P.T (perseroaan terbatas), N.V (Namloze Vennootschap) dan yayasan (Sticthing), bahkan negarapun juga merupakan badan hukum.

Rudhi Prasetya menyatakan secara umum korporasi mempunyai unsur-unsur antara lain; a) Kumpulan orang dan atau kekayaan, b) Terorganasir, c) Badan hukum, dan d) Non badan hukum. Pada pepsektif ini, bentuk-bentuk kejahatan korporasi dapat diklasifikasilan menjadi 3 (tiga) macam, yaitu:

1. Kejahatan korporasi dibidang ekonomi, antara lain berupa perbuatan tidak melaporkan keuntungan perusahaan yang sebenarnya, menghindari atau memperkecil pembayaran pajak dengan cara melaporkan data yang tidak sesuai dengan keadaan yang sebenarnya, persekongkolan dalam penentuan harga, memberikan sumbangan kampanye politik secara tidak sah;

2. Kejahatan korporasi dibidang sosial budaya, antara lain; kejahatan hak cipta, kejahatan terhadap buruh, kejahatan narkotika dan psikotropika; dan
3. Kejahatan korporasi yang menyangkut masyarakat luas. Hal ini dapat terjadi pada lingkungan hidup, konsumen dan pemegang saham.

Adapun pertanggungjawaban Pidana oleh pengurus korporasi, adalah bahwa di dalam korporasi atau perusahaan, para anggota direksi dan komisaris sebagai salah satu organ vital dalam badan hukum tersebut merupakan pemegang amanah (fiduciary) yang harus berperilaku sebagaimana layaknya pemegang kepercayaan.

Di sini komisaris dan direktur memiliki posisi fiducia dalam pengurusan perusahaan dan mekanisme hubungannya harus secara fair. Menurut pengalaman common law hubungan itu dapat didasarkan pada teori fiduciary duty. Hubungan fiduciary duty tersebut didasarkan atas kepercayaan dan kerahasiaan (trust and confidence) yang dalam peran ini meliputi, ketelitian (scrupulous), itikad baik (good faith), dan keterusterangan (candor).

Dalam memahami hubungan pemegang kepercayaan (fiduciary relationship) tersebut, common law mengakui bahwa orang yang memegang kepercayaan (fiduciary) secara natural memiliki potensi untuk menyalahgunakan wewenangnya. Oleh sebab itu hubungan pemegang kepercayaan tersebut harus didasarkan kepada standar yang tinggi, untuk tidak menyalagunakan kewenangan melakukan tindak pidana.

Perspektif tindak pidana korporasi di lingkungan hidup, dapat dinyatakan bahwa kejahatan terhadap lingkungan hidup berupa pencemaran dan/atau perusakan kondisi tanah, air dan udara suatu wilayah. Dengan demikian dalam kejahatan lingkungan hidup dapat ditafsirkan lebih luas dalam konteks kerusakan yang berakibat luas, mengakibat bencana dan merugikan pada umat manusia berupa pencemaran.

Hukum pidana dalam Undang-Undang Nomor 32 Tahun 2009 tentang Perlindungan dan 
Pengelolaan Lingkungan Hidup, memperkenalkan ancaman minimum disamping maksimum, perluasan alat bukti, pemidanaan bagi pelanggaran baku mutu, keterpaduan penegakan hukum pidana dan pengaturan tindak pidana korporasi.

Kedudukan lingkungan hidup yang baik dan sehat sebagai salah satu hak asasi dan hak konsitusional bagi warga negara yang sinergi dengan pembangunan nasional yang diselenggarakan dengan prinsip pembangunan berkelanjutan dan berwawasan nusantara. Dasarnya menjadi kebutuhan dan penentu sistem penyanggah kehidupan, lingkungan yang baik dan sehat memberikan manfaat yang besar bagi umat manusia. Oleh karena itu negara, pemerintah dan seluruh masyarakat berkewajiban untuk melakukan perlindungan dan pengelolaan lingkungan hidup.

Tindak pidana korporasi pada UndangUndang Nomor 32 Tahun 2009 menyebutkan dalam Pasal-Pasal Undang-Undang Nomor 32 Tahun 2009 tersebut yang dapat di katagorikan terkait dengan tindak pidana korporasi antara lain diatur dalam pasal 116-120. Pasal 116 ayat (1), tindak pidana lingkungan dilakukan oleh, untuk dan atas nama badan usaha, tuntutan pidana dan sanksi pidana dijatuhkan pada a) Badan usaha; dan/atau, b) Orang yang memberi perintah untuk melakukan tindak pidana tersebut atau orang yang bertindak sebagai pemimpin kegiatan tindak pidana tersebut.

Dengan demikian yang bertangggungjawab adalah badan usaha atau orang yang memberi perintah untuk melakukan tindak pidana. Dalam hal ini juga berlaku pada tindak pidana lingkungan hidup dilakukan orang, yang berdasarkan hubungan kerja atau berdasarkan hubungan lain yang bertindak dalam lingkup kerja badan usaha. Sanksi pidana dijatuhkan tetap pada pemberi perintah atau pemimpin dalam tindak pidana tersebut tanpa memperhatikan tindak pidana tersebut dilakukan secara sendiri atau bersama-sama.

Tuntutan pidana pada tindak pidana korporasi pada lingkungan hidup, pemberi perintah tindak pidana, ancaman pidana yang dijatuhkan berupa pidana penjara dan denda diperberat dengan sepertiga (pasal 117). Sedangkan tindak pidana yang dilakukan badan usaha, sanksi pidana dijatuhkan kepada badan usaha yang diwakili oleh pengurus yang berwenang mewakili di dalam dan diluar pengadilan sesuai dengan peraturan perundang-undangan selaku pelaku fungsional.

Penjelasan Undang-Undang Nomor 32 Tahun 2009, pelaku fungsional adalah badan usaha dan badan hukum. Tuntutan pidana dikenakan terhadap pemimpin badan usaha dan badan hukum, karena tindak pidana badan usaha dan badan hukum adalah tindak pidana fungsional, sehingga pidana dikenakan dan sanksi dijatuhkan kepada mereka yang memiliki kewenangan terhadap pelaku fisik dan menerima tindakan pelaku fisik tersebut.

Khusus mengenai sanksi atau pidana tambahan, bahwa di dalam tindak pidana korporasi pada lingkungan hidup juga dikenakan pidana tambahan. Pasal 119 menyebutkan bahwa selain pidana sebagaimana dimaksud dalam undangundang ini, terhadap badan usaha dapat dikenakan pidana tambahan atau tindakan tata tertib berupa a) Perampasan keuntungan yang diperoleh dari tindak pidana, b) Penutupan seluruh atau sebagian tempat usaha dan/atau kegiatan, c) Perbaikan akibat tindak pidana, d) Kewajiban mengerjakan apa yang dilalaikan tanpa hak; dan/atau, e) Penempatan perusahaan dibawah pengampuan paling lama 3 (tiga) tahun.

Pelaksanaan ketentuan Pasal 199 Huruf a, b, c dan $\mathrm{d}$, jaksa berkoordinasi dengan instansi yang bertanggungjawab dibidang perlindungan dan pengelolaan lingkungan hidup untuk melaksanakan eksekusi. Undang-Undang Nomor 32 Tahun 2009 sudah jelas, pengaturan yang menyangkut pertanggungjawaban tindak pidana korporasi. Selain itu, diperlukan studi yang lebih mendalam baik di kalangan akademis, profesional maupun aparat penegak hukum guna membangun suatu kerangka 
teoritis bagi pertanggungjawaban pidana korporasi.

Hal ini hendaknya diimbangi pula dengan upaya peningkatan kualitas dan kemampuan para penegak hukum yang akan menerapkannya. Mereka harus mampu dan kreatif untuk melakukan terobosan hukum, dalam penegakan tindak pidana korporasi dalam lingkungan hidup yang sudah diatur dalam Undang-Undang Nomor 32 Tahun 2009, harus menjadi acuan dalam penegakannya.

Ke depan perlu adanya sosialisasi UndangUndang Nomor 32 Tahun 2009 terhadap penerapan sanksi pidana bagi aparat penegak hukum, untuk lebih memperhatikan penafsiran asas ultimum remedium. Karena disadari atau tidak bahwa dewasa ini masalah pencemaran lingkungan hidup semakin meningkat dari waktu, ke waktu, baik kegiatan pencemaran lingkungan yang dilakukan oleh individu maupun oleh badan hukum (korporasi). Kejahatan lingkungan hidup yang dilakukan oleh korporasi patut kita waspadai, karena kejahatan lingkungan hidup yang dilakukan oleh korporasi adalah yang paling potensial pada masa kini dan tentu saja sangat memiliki dampak yang berbahaya bagi kelangsungan lingkungan hidup dan sekitarnya.

Bahkan Barda Nawawi Arif $(2001,34)$, memaparkan hal-hal yang menjadi masalah sentral dunia saat ini adalah perkembangan kongreskongres PBB mengenai the prevention of crime and the treatment offenders dalam dua dekade terakhir ini sering menyoroti bentuk-bentuk dimensi kejahatan terhadap pembangunan (crime against development), kejahatan terhadap kesejahteraan social (crime against social welfare), dan kejahatan terhadap kualitas lingkungan hidup (crime against the quality of life).

Pembangunan yang terjadi secara besar-besaran dan tanpa memperhatikan aspek lingkungan menjadi persoalan utama bagi lingkungan hidup. Keterkaitan masalah-masalah pembangunan de- ngan masalah kesejahteraan masyarakat dan masalah lingkungan hidup pada prinsipnya tidak dapat dipisahkan.

Dewasa ini masalah lingkungan hidup menjadi paling hangat untuk disoroti oleh berbagai pihak. Hal ini karena lingkungan hidup sangat erat kaitannya dengan kelangsungan makhluk hidup dan kesejahteraan makhluk hidup. Dengan melihat besarnya pengaruh korporasi dalam pencemaran lingkungan hidup dewasa ini, maka sudah selayaknya apabila korporasi tersebut dimintai pertanggung jawaban secara pidana.

International Amnesty (2003) dan Human Rights Watch (2004) melaporkan berbagai bisnis internasional terlibat luas dalam pelanggaran Hak Asasi Manusia di daerah operasi mereka di seluruh dunia mulai penyiksaan pekerja, penggusuran, penyingkiran paksa, menghambat buruh berserikat, melanggar hak-hak dasar pekerja perempuan, mempekerjakan buruh anak, hingga mengobrak-abrik hak-hak masyarakat adat, serta merusak lingkungan hidup.

Sebagai respons, konsepsi CSR yang merupakan bentuk tanggung jawab korporasi, mulai digiatkan lagi kepada komunitas bisnis. Padahal, ia bukan hal baru. CSR sudah ada sebagai bagian dari strategi bisnis dalam upaya menambah nilai positif perusahaan di mata publik. Lewat gugatan ketat logika para pemodal, tanggung jawab korporasi ini membuahkan dilema.

Di satu sisi, CSR merupakan klaim atas inisiatif yang menunjuk bahwa bisnis tak hanya beroperasi untuk kepentingan para pemegang saham (shareholders), tapi juga untuk kemaslahatan pihak stakeholders dalam praktik bisnis, yaitu para pekerja, komunitas lokal, pemerintah, LSM, konsumen, dan lingkungan hidup. Global Compact Initiative (2002) menyebut pemahaman ini dengan 3P (profit, people, planet). Yaitu, bahwa sementara tujuan bisnis adalah mencari laba (profit), ia seharusnya juga menyejahterakan orang (people), dan menjamin keberlanjutan hidup planet ini. 
Penegakan hukum pidana lingkungan dapat berupa preventif dan represif. Penegakan hukum pidana lingkungan yang bersifat preventif adalah penegakan hukum sebelum terjadinya pelanggaran atau pencemaran lingkungan hidup. Hal ini erat kaitannya dengan masalah administrasi lingkungan, yaitu pemberian izin. Dalam pemberian izin usaha, pemerintah hendaknya memperhatikan dampak social dan dampak lingkungan hidup yang akan timbul dari kegiatan usaha tersebut.

Sedangkan penegakan hukum pidana lingkungan yang bersifat represif adalah penegakan hukum setelah terjadinya pencemaran lingkungan hidup. Hukum lingkungan, penegakan hukum secara preventif harus lebih diutamakan, karena penanggulangan akibat pencemaran melalui penegakan hukum represif memerlukan biaya yang sangat besar. Di samping itu kerugian yang akan diderita oleh lingkungan sebagai akibat dari pencemaran, tidak mungkin dapat dipulihkan kembali dalam waktu yang cepat. Koesnadi (2005, 56), berpendapat bahwa upaya penegakan hukum lingkungan yang harus dilakukan lebih dahulu adalah yang bersifat compliance, yaitu pemenuhan peraturan, atau penegakan hukum preventifnya dengan pengawasannya.

Sementara itu, penerapan hukum pidana dalam kasus-kasus pencemaran lingkungan perlu memperhatikan asas subsidaritas sebagai berikut sebagai penunjang hukum administrasi, berlakunya hukum pidana tetap memperhatikan asas subsidaritas yaitu hendaknya hukum pidana didayagunakan apabila sanksi dibidang hukum lain, seperti sanksi administratif, dan sanksi perdata, dan alternative penyelesaian sengketa lingkungan hidup tidak efektif dan/atau tingkat kesalahan pelaku relative berat dan/atau akibat perbuatannya lebih besar dan/atau perbuatannya menimbulkan keresahan di masyarakat.

Perspektif ini, permasalahan pindana berkaitan dengan badan hukum dapat diklarifikasi ketika menjadi subyek hukum sebagai berikut;
1. Tidak pernah memikirkan adanya eksistensi badan hukum atau korporasi. Perbuatan yang dilakukan dalam hubungannya dengan korporasi harus dipandang sebagai perbuatan yang dilakukan oleh pengurus korporasi, jadi penguruslah yang bertanggung jawab. Pendapat ini mengacu pada asas umum dalam Kitab Undang-Undang Hukum Pidana (KUHP), yaitu bahwa sebuah perbuatan pidana hanya dapat dilakukan oleh manusia (naturlijke person). Hal ini dapat dilihat dalam rumusan pasal 59 KUHP yang berbunyi; jika ditentukan pidana karena pelanggaran bagi pengurus, anggota badan pengurus atau komisaris, maka pidana itu tidaklah dijatuhkan atas anggota pengurus atau komisaris, jika terang bahwa pelanggaran itu terjadi bukan karena kesalahannya;

2. Mengakui korporasi sebagai pembuat namun yang harus bertanggung jawab adalah pengurusnya;

3. Mengakui bahwa korporasi dapat menjadi pembuat dan yang bertanggung jawab. Pendapat ini merupakan pendapat yang paling maju yang menganggap korporasi sebagai subjek hukum sehingga dapat dipertanggung jawabkan secara pidana.

Latar belakang dari pemikiran ini, sehingga korporasi dapat dijatuhi hukuman pidana antara lain karena ada anggapan bahwa keuntungan materi yang diperoleh oleh korporasi dari hasil usahanya amatlah besar, maka pidana yang dijatuhkan kepada pengurus dirasa tidak seimbang dan tidak menjamin korporasi untuk tidak mengulangi perbuatan pidana tersebut.

Perbuatan tercela dan kejahatan terhadap lingkungan tidak hanya manusia sebagai badan pribadi yang dapat melakukannya, akan tetapi korporasi sebagai suatu badan hukum dapat pula melakukan perbuatan itu yang dapat menimbulkan kerugian bagi pihak lain, baik individu atau masyarakat. 
Pelaksanaan korporasi sebagai subjek hukum yang dapat bertanggung jawab dalam delik lingkungan tetap harus melihat unsur kesalahan dalam perbuatan pidana yang dilakukan oleh korporasi. Pembuat suatu perbuatan pidana hanya akan dipidana jika ia mempunyai kesalahan dalam melakukan perbuatan pidana tersebut. Dalam ilmu hukum hal ini kita kenal dengan asas " tiada pidana tanpa kesalahan (geen straf zoonder schuld)".

Bertentangan dengan rasa keadilan, apabila ada orang yang dijatuhi pidana padahal ia sama sekali tidak bersalah atau ia tidak memiliki unsur kesalahan yang dapat dicelakan kepadanya sebagai pertanggung jawaban. Untuk menentukan adanya kesalahan pada seseorang harus memenuhi beberapa unsur, yaitu; a) Adanya kemampuan bertanggung jawab si Pembuat, b) Hubungan batin antara si Pembuat dengan perbuatannya yang berupa kesengajaan atau kealpaan. c) Tidak adanya alasan penghapus kesalahan atau tidak ada alasan pemaaf maupun pembenar.

Bab IX Undang-undang Nomor 23 tahun 1997 tentang Pengelolaan Lingkungan Hidup, telah diatur sanksi pidana (penjara dan denda) terhadap badan hukum yang melakukan pencemaran. Selanjutnya, pada pasal 46 Undang-Undang Nomor 23 Tahun 1997 dinyatakan bila badan hukum terbukti melakukan tindak pidana, maka sanksinya dijatuhkan selain terhadap badan hukum, juga terhadap mereka yang memberi perintah atau yang menjadi pemimpin dalam perbuatan tersebut.

Kejahatan korporasi dalam sistim hukum Indonesia, tidak hanya dikenal dalam Undangundang Nomor 23 Tahun 1997. Undang-undang Pemberantasan Korupsi dan Undang-undang Anti Tindak Pidana Pencucian Uang (money laundering) juga mengatur pertanggungjawaban atas kejahatan korporasi. Sally S. Simpson menyatakan "corporate crime is a type of white-collar crime". Sedangkan Simpson, mengutip John Braithwaite, mendefinisikan kejahatan korporasi sebagai "conduct of a cor- poration, or employees acting on behalf of a corporation, which is proscribed and punishable by law".

Pespektif ini, korporasi sebagaimana diatur dalam pasal 45 dan 46 Undang-undang Nomor 23 Tahun 1997 merupakan rumusan kejahatan korporasi sebagaimana diatur dalam KUHP Belanda. Jadi korporasi sebagai legal persoon, dapat dipidana berdasarkan Undang-undang Nomor 23 Tahun 1997. Menurutnya, pertanggungjawaban pidana (criminal liability) dari pimpinan korporasi (factual leader) dan pemberi perintah (instrumention giver), keduanya dapat dikenakan hukuman secara berbarengan. Hukuman tersebut bukan karena perbuatan fisik atau nyatanya, akan tetapi berdasarkan fungsi yang diembannya di dalam suatu perusahaan.

Dengan demikian, seharusnya didakwa bukan hanya korporasi tapi juga individu-individu yang dianggap bertanggung jawab atas pencemaran tersebut, termasuk direkturnya. Stefanus menjelaskan, perlu ada pemahaman bahwa dalam hukum pidana ada asas kulpabilitas, sehingga harus dibuktikan bahwa seseorang bisa dipidana apabila memang terbukti bersalah. Artinya tidak bisa secara otomatis sanksi pidana dialihkan dari corporate crime menjadi personal crime.

Jadi harus dipisahkan sanksi terhadap korporasi dan juga individu. Memang logikanya jika korporasinya bersalah maka direksinya juga bersalah, karena yang melakukan tindakan korporasi adalah direksi. Namun, dalam hukum pidana, mutlak harus dibuktikan adanya niat untuk melakukan perbuatan pidana. Inilah yang dimaksud asas mens rea (guilty mind) yang dikatakan oleh Stevanus." an act is a crime because the person committing it intended to do something wrong, This mental state is generally referred to as Mens rea".

Perspektif ini bahwa lembaga peradilan memang agak canggung untuk membawa korporasi ke pengadilan. Namun perlu diingat, bahwa pernah ada dua kasus serupa yang pernah diputus oleh pengadilan, dimana direktur perusahaan 
dijatuhi pidana kurungan karena tindak pidana yang dilakukan oleh perusahaan.

Mengenai dugaan pelanggaran izin yang diperoleh korporasi. Stefanus berpendapat hal tersebut harus dibuktikan terlebih dahulu, "Kalau yang dilanggar adalah hukum administrasi berarti dia melanggar perizinan. Jadi harus dibuktikan apakah korporasi melanggar ambang batas yang ditentukan dalam izin. Baru diperiksa apakah pelanggaran terhadap ambang batas tersebut menimbulkan pencemaran.

Dengan demikian manakala pelanggaran ini menimbulkan pencemaran, maka korporasi bertanggung jawab secara pidana dan juga perdata. "Yang berlaku dalam Undang-undang Lingkungan adalah delik formal. Artinya begitu terbukti melanggar hukum administrasi (ambang batas) maka sekaligus melanggar hukum pidana.

\section{Penutup}

Bahwa perkembangan Badan Hukum berupa korporasi mulai dari abad pertengahan hingga abad ini, cukup memberikan informasi untuk mencari hubungan antara pertumbuhan korporasi yang pesat dengan timbulnya kejahatan korporasi dalam lapangan hukum pidana. Masih diperlukan kajian yang lebih intensif mengenai kejahatan korporasi tersebut.

Bahwa korporasi multinasional telah menunjukkan akumulasi kekayaan besar-besaran, dan menciptakan jarak yang lebar antar personal. Ada yang sangat kaya dan masih sangat banyak yang miskin. Bahkan korporasi besar, begitu mendominasi sistem ekonomi dunia, dan dapat menentukan pekerjaan bagi banyak orang, makanan, minuman dan pakaian, dan sebagainya. Korporasi dapat pula mengancam pemerintahan suatu negara di mana korporasi itu beroperasi.

Bahwa hukum lingkungan merupakan bidang hukum yang disebut dengan bidang hukum fungsional, yaitu sebuah bidang hukum yang mengan- dung ketentuan-ketentuan hukum administrasi negara, pidana dan perdata. Pertanggungjawaban korporasi tidak diatgur secara tegas dalam UU Nomor 39 Tahun 2009 Tentang Perlindungan dan Pengelolaan lingkungan Hidup. Hal demikian menyebabkan sulitnya tindak pidana korporasi diterapkan berdasarkan delik lingkungan.

Bahwa kesulitan tanggungjawab korporasi atas delik lingkungan disebabkan adanya ideologi, Undang-Undang Tentang Perlindungan dan Pengelolaan lingkungan Hidup telah secara tegas mengadopsi asas-asas yang terkandung dalam Delarasi Rio 1992, yaitu asas-asas tanggungjawab negara, keterpaduan, kehati-hatian, keadilan, pencemar membayar, partisipatif dan kearifan lokal. Pengadopsian ini merupakan politik hukum yang penting karena dapat memperkuat kepentingan pengelolaan lingkungan hidup manakala berhadapan dengan kepentingan ekonomi jangka pendek. Namun akomodasi delik lingkungan dengan pertanggungjawaban korporasi masih lemah.

\section{DAFTAR PUSTAKA}

\section{Buku}

Amanwinata, 2010, Delik Delik Tersebar di Luar KUHP, Politeia, Bandung.

Amintohari, 2010, Bencana Bencana Abad Ini, Siapa Bersalah dan Bertanggungjawab?, Lukito, Surabaya.

Anam, Choirul., 2011, Perbandingan Sistem Hukum, eropa Kontinental dan Anglo Amerika, Sebuah Telaah Praktis, Dian Rana, Yogyakarta.

Arief, Barda Nawawi, 2001, Tindak Pidana Korporasi, Rajawali Press, Bandung.

Hardjasoemantri, Koesnadi, 2005, Hukum Lingkungan, Universitas Gadjahmada Press, Yogyakarta.

Hariyadi, 2012, Banjir Dimana-mana; Bagimana Peran Institusi Pelestarian Lingkungan?, Panepen Mukti, Solo.

Karmanto, Guntur, 1999, Korporasi, Permasalahan dan Prospeknya, Putra Kelana, Jakarta. 


\section{Jurnal Cakrawala Hukum}

Vol.7, No.2 Desember 2016: 216-228

Nasrudin, Dahlan, 2010, Aspek Pidana dari Analisis Mengenai Dampak Lingkungan, Pustaka, Yogyakarta.

Ndaru, Suwito, 2010, Badan hukum, Perkembangan dan Masalahnya, Universitaria, Solo.

Rahayu, Umirah, 2010, Ketika Bencana Lingkungan Datang Silih Berganti; Apa Yang Harus Dilakukan?, Satyawacana, Salatiga.

Rangkuti, Siti Sundari, 1998, Hukum Lingkungan di indonesia, Airlangga Universiti Press, Surabaya.

Remellink, Jan, 1978, Hukum Pidana, Politeia, Bandung.

Santoso, Budi, 2011, Peran Polri dari Tindak Pidana Konvensional ke Tindak Pidana Trans nasional, Sutrindo, Bandung.
Syahdeini, Sutan Remi, 1998, Tindak Pidana Korporasi pada Instansi Perbankan, Amelia, Surabaya.

Tanujaya, Patuwi, 2010, Aspek Administrasi Lingkungan Hidup dalam UU No. 32 tahun 2009 Tentang Perlindungan dan pengelolaan Lingkungan Hidup, Lentera, Bandung.

Tasrifin, 2011, Menerapkan Pidana Untuk Korporasi Delik Lingkungan Hidup, Mungkinkah?, Opini pada Dinamika Berita, Banjarmasin.

Wilardi, Romli, 2010, Perkembangan Asas dan Norma Hukum Administrasi Negara, LP3MN, Yogyakarta. 